\title{
SUGAR FEEDING ENHANCES ROOT VIGOR OF YOUNG TREES FOLLOWING CONTAINERIZATION
}

\section{By Glynn C. Percival}

\begin{abstract}
The influence of sugar (sucrose) applied as a root drench at 25,50 , or $70 \mathrm{~g}(0.9,1.8$, or $2.7 \mathrm{oz})$ per liter of water on root and shoot vigor, leaf chlorophyll fluorescence, photosynthetic rates, and chlorophyll content in silver birch (Betula pendula), red oak (Quercus rubra), cherry, (Prunus avium), and rowan, (Sorbus aucuparia) was investigated. In silver birch, cherry, and red oak, applications of sugar $\leq 50 \mathrm{~g}(1.8 \mathrm{oz})$ per liter of water significantly enhanced root vigor (root length, number of new roots formed, root dry weight) by week 12 . Applications of sugar at $70 \mathrm{~g}(2.7 \mathrm{oz})$ per liter of water had no significant effect on root vigor except in silver birch where root dry weight at the cessation of the experiment was significantly improved. Irrespective of species, no significant effects on tree vitality as measured by leaf chlorophyll fluorescence, photosynthetic rates, and chlorophyll concentrations were recorded. Effects on shoot growth were variable with a significant enhancement recorded in some, but not all, of the test species. Results indicate application of sugars as a soil drench may be able to aid in the establishment of newly planted trees by improving root vigor post transplanting.
\end{abstract}

Key Words. Urban trees; carbohydrates; resource allocation; gene expression; transplant shock; Betula pendula; Quercus rubra; Prunus avium; Sorbus aucuparia.

It has long been accepted that drought-related problems are often responsible for poor growth and deaths of newly planted urban trees (Davies 1998). As little as 5\% of a tree's root system may be moved with a tree following lifting from the nursery bed, in turn significantly reducing the root: shoot ratio and consequently the tree's ability to uptake sufficient water and nutrients for survival of the newly expanding leaf canopy in spring. This leads to water stress, resulting in "transplant shock" that may be characterized by reduced shoot growth, branch dieback, and, ultimately, tree death. Although tree root systems can be manipulated to reduce the effects of transplant shock by increasing the amount of root to be transplanted by, for example, root pruning, pulling out of the ground (wrenching), or undercutting in the nursery, the effects of these techniques are inconsistent, and a high proportion of the root system may still be lost in the lifting process (Percival and Gerritsen 1998; Davies et al. 2002)

A number of factors have been associated with transplant shock; however, it is now widely believed that survival of newly planted trees is largely dependent on rapid extension of roots that absorb water to replenish transpira- tional water loss and reduce water stress (Gilbertson and Bradshaw 1990; Watson and Himelick 1997). Ideally an inexpensive, nontoxic, and environmentally friendly compound that can be applied to a tree's root system postplanting to stimulate root vigor and restore the root:shoot ratio is required.

Trees are planted in urban environments for practical, ecological, and psychological benefits; however, survival, establishment, and reproduction (seed set) are critical for the success of the next tree generation (Percival and Hitchmough 1995). These objectives can be achieved only by the production and expenditure of energy by the tree, which, in turn, is achieved by photosynthesis:

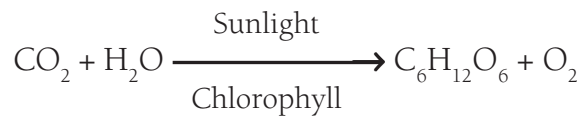

Previous research has studied alterations to plant growth and development in the presence of high and low concentrations of carbon dioxide, water, and oxygen (Hall and Rao 1999). Surprisingly, the influence of sugar feeding (the end product of photosynthesis) on plant physiological processes has received little scientific investigation. Of the limited literature available, supplementing root systems with sugar in the form of sucrose has been shown to affect root metabolism by significantly increasing lateral root branching and root formation in wheat and barley (Bingham and Stevenson 1993; Bingham et al. 1997; 1998). Work elsewhere (Fuchs 1986) also demonstrated that root regeneration of Rosa multiflora 'Kanagawa' was improved more by application of sucrose/auxin combinations compared to auxins alone. This finding indicates that the growth pattern of trees may be altered in favor of enhanced root formation by treating them during or immediately after transplanting with sugar, potentially offering a system for reducing tree mortalities due to transplant shock.

As a prerequisite to larger tree studies, the objectives of this investigation, using small potted trees, were to (1) evaluate the influence of sugar (sucrose) on root and shoot vigor, chlorophyll fluorescence, photosynthesis, and leaf chlorophyll concentrations of four tree species following containerization to simulate transplant conditions; and (2) evaluate three application rates, 25,50 , or $70 \mathrm{~g}(0.9,1.8$, or $2.7 \mathrm{oz}$ ) sugar per liter of water, on those responses. 


\section{MATERIALS AND METHODS}

The experiment used 4-year-old, cell-grown stock of four commonly planted urban tree species, Betula pendula (silver birch), Quercus rubra (red oak), Prunus avium, (cherry), and Sorbus aucuparia, (rowan) approximately $45 \mathrm{~cm}$ (18 in.) high, $\pm 4.5 \mathrm{~cm}$ (1.8 in.), obtained from a commercial supplier. Six months prior to experiments (early November), trees were potted into $4.5 \mathrm{~L}$ (1 gal.) plastic pots filled with soil [loamy texture, $24 \%$ clay, $45 \%$ silt, $31 \%$ sand, $3.1 \%$ organic carbon, pH 6.6, supplemented with the controlled release nitrogenbased (N:P:K 20:8:8) fertilizer 'Enmag' (Salisbury House, Weyside Park, Goldmar, Surrey, UK) at a rate of $1 \mathrm{~g} / \mathrm{kg}(0.04$ oz/36 oz) soil]. Following potting, trees remained outdoors subject to natural environmental conditions and watered as required. In early March, trees were moved to a polythene tunnel to protect against possible spring frosts. As soon as the initial symptoms of budburst were observed (i.e., leaf emergence, mid-April), trees were placed under glasshouse conditions $\left[22^{\circ} \mathrm{C} \pm 2{ }^{\circ} \mathrm{C}\left(72^{\circ} \mathrm{F} \pm 3.6^{\circ} \mathrm{F}\right)\right]$ and supplemented with 400W, high-pressure sodium lamps (SON/T) providing a photoperiod of $16 \mathrm{~h}$ light $/ 8 \mathrm{~h}$ dark and minimum 250 $\mu \mathrm{mol} \mathrm{m} \mathrm{s}^{-2}$ photosynthetically active radiation (PAR) at the tree crown. Sugar feeding commenced in early May when all species were in full leaf. Root drenches of sucrose, obtained from a local supermarket, at a concentration of either 25 , 50 , or $70 \mathrm{~g}(0.9,1.8$, or $2.7 \mathrm{oz})$ sugar per liter of water were applied. Each tree received 0.5 L (17 oz) of sugar solution at day 7 and 21 following leaf expansion. A sugar solution of $0.5 \mathrm{~L}$ was deemed sufficient to fully saturate the soil because, at that amount, solution was observed emerging from drainage holes. During the period between days 7 and 21 under glass, trees were watered as required (day 11 and 17). Watering with water only served as the control. After day 21 (late May), trees were returned outdoors and subject to natural weather conditions until the cessation of the experiment at week 12. Climatic conditions from day 21 to week 12 were recorded. Mean minimum and maximum air temperatures were $7.4^{\circ} \mathrm{C}\left(44.5^{\circ} \mathrm{F}\right)$ and $28.4^{\circ} \mathrm{C}\left(83^{\circ} \mathrm{F}\right)$, respectively. Daily relative humidity, sunshine hours, and rainfall were $79.7 \%, 9.45 \mathrm{~h}$, and $2.56 \mathrm{~cm}$ (1.02 in.), respectively. The soil surface temperature was $2.4^{\circ} \mathrm{C}\left(37^{\circ} \mathrm{F}\right)$, and soil temperatures at $20 \mathrm{~cm}\left(8 \mathrm{in}\right.$.) depth averaged $8.8^{\circ} \mathrm{C}$ $\left(48^{\circ} \mathrm{F}\right)$ (Reading University Meteorological Department, Whiteknights, Reading, UK). Experiments were undertaken in 2001 and repeated in 2002 using six trees per treatment. Climatic data represents mean of both 2001 and 2002 trials. Under both glasshouse and outdoor conditions, the experimental design used was completely randomized, and trees were re-randomized on a weekly basis.

At weeks 1, 3, 6, 9, and 12 after sugar treatments, leaves were adapted to darkness for $30 \mathrm{~min}$ by attaching lightexclusion clips to the leaf surface, and chlorophyll fluorescence was measured using a HandyPEA portable fluorescence spectrometer (Hansatech Instruments Ltd., King's Lynn, UK). Measurements were recorded up to $1 \mathrm{~s}$ with a data acquisition rate of $10 \mu \mathrm{s}$ for the first $2 \mathrm{~ms}$ and of $1 \mathrm{~ms}$ thereafter. The fluorescence responses were induced by a red (peak at $650 \mathrm{~nm}$ ) light of $1500 \mu \mathrm{mol} \mathrm{m}{ }^{-2} \mathrm{~s}^{-1}$ photosynthetically active radiation (PAR) intensity provided by an array of six light-emitting diodes. The ratio of variable $(\mathrm{Fv}=\mathrm{Fm}-\mathrm{Fo})$ to maximal (Fm) fluorescence (i.e., $\mathrm{Fv} / \mathrm{Fm}$ where $\mathrm{Fo}=$ minimal fluorescence) of dark-adapted leaves were used to quantify any effects on leaf tissue. Fv/Fm is considered a quantitative measure of the maximal or potential photochemical efficiency or optimal quantum yield of photosystem II (Willits and Peet 2001). Likewise, Fv/Fm values are the most popular index used as a measure of plant vitality and early diagnostic of stress (Meinander et al. 1996).

Leaf chlorophyll content was measured at the midpoint of the leaf next to the main leaf vein using a Minolta chlorophyll meter SPAD-502. Calibration was obtained by measurement of absorbance at 663 and $645 \mathrm{~nm}$ in a spectrophotometer (PU8800 Pye Unicam) after extraction with $80 \% \mathrm{v} / \mathrm{v}$ aqueous acetone (regression equation $=5.80$ $+0.057 x ; r^{2}$ adj $=0.82, P=<0.01$ ) (Lichtenthaler 1987).

At the first sampling date, five leaves per tree were used for chlorophyll fluorescence and chlorophyll content measurements randomly selected throughout the crown. Leaves were then tagged to ensure only the same leaf was measured repeatedly throughout the experimental period.

The light-induced $\mathrm{CO}_{2}$ fixation ( $\mathrm{Pn}$ ) was measured in predarkened (20 min), fully expanded leaves from near the top of the canopy (generally about number four counting down from the apex) using an infrared gas analyzer (LCA-2 ADC). The irradiance on the leaves was 700 to $800 \mathrm{~mol} \mathrm{~m}^{-2}$ photosynthetically active radiation saturating with respect to $\mathrm{Pn}$; the velocity of the airflow was $1 \mathrm{~mL} \mathrm{~s}^{-1} \mathrm{~cm}^{-2}\left(0.4 \mathrm{in}^{-2}\right)$ of leaf area. Calculation of the photosynthetic rates was carried out according to von Caemmerer and Farquhar (1981). Readings were taken at weeks 3, 6, and 12. Two leaves per tree were selected for measurements.

Although new leaf formation was observed in all species between weeks 6 and 7 post sugar application, no measurements of newly formed leaf tissue were made.

At the conclusion of the experiment (week 12), trees were destructively harvested. Leaf, shoot, and root dry weight were recorded after oven drying at $85^{\circ} \mathrm{C}\left(185^{\circ} \mathrm{F}\right)$ for $48 \mathrm{~h}$. Leaf areas were quantified using a Delta-T area meter. Compost was gently removed from the root system by washing with water through a $4 \mathrm{~mm}(0.2 \mathrm{in}$.) screen. The number of new white roots larger than $1 \mathrm{~cm}(0.4 \mathrm{in}$.) was counted as a measure of the root growth potential (RGP), and the root length (the straight line distance from the trunk to the furthest root tip) was measured.

Effects of sugar feeding on chlorophyll fluorescence, photosynthetic rates, chlorophyll concentrations as mea- 
sures of tree vitality, growth, and any significant interactions between sugar and species were determined by both twoand one-way analyses of variance (ANOVA) following checks for normality and equal variance distributions. Differences between treatment means were separated by the least significance difference (LSD) at the 95\% confidence level $(P>0.05)$ using the Genstat V program. Based on Student's t-test, treatment effects on tree vitality and growth of each species did not significantly differ between years; consequently, values represent pooled data for both 2001 and 2002 experiments.

\section{RESULTS AND DISCUSSION Tree Vitality}

Irrespective of species and concentration of sugar applied, no significant improvements in tree vitality as assessed by leaf chlorophyll fluorescence, photosynthetic rates, and chlorophyll content were recorded (Figures 1, 2, and 3*). Fluorescence values for all four species ranged from 0.6 to 0.8 , photosynthetic rates from 5 to $8 \mathrm{CO}_{2} \mathrm{mmol} \mathrm{m}^{-2} \mathrm{~s}^{-1}$, and leaf chlorophyll content from 40 to $80 \mathrm{mg} / \mathrm{g}$ fresh weight. Significant improvements in tree growth $(P<0.05$, Table 1) as a result of sugar feeding indicate improvements in tree vitality by alterations to other plant physiological processes not investigated in this experiment, such as synthesis of sugar-induced, stress-protectant metabolites and/or induction of systemic-induced resistance (Herbers et al. 1996; Naidu 1998; Williamson et al. 2002). Results of a twoway ANOVA (species and sugar) also indicates that sugar feeding did not influence chlorophyll fluorescence, photosynthetic rates, or chlorophyll content of the four test species (Table 2). Regardless of species, leaf chlorophyll fluorescence and chlorophyll content values were lowest at week 1 compared to weeks 3, 6, and 9. Research elsewhere

Table 1. The influence of sugars (sucrose) on growth of silver birch, red oak, cherry, and rowan at week 12 applied as a soil drench.

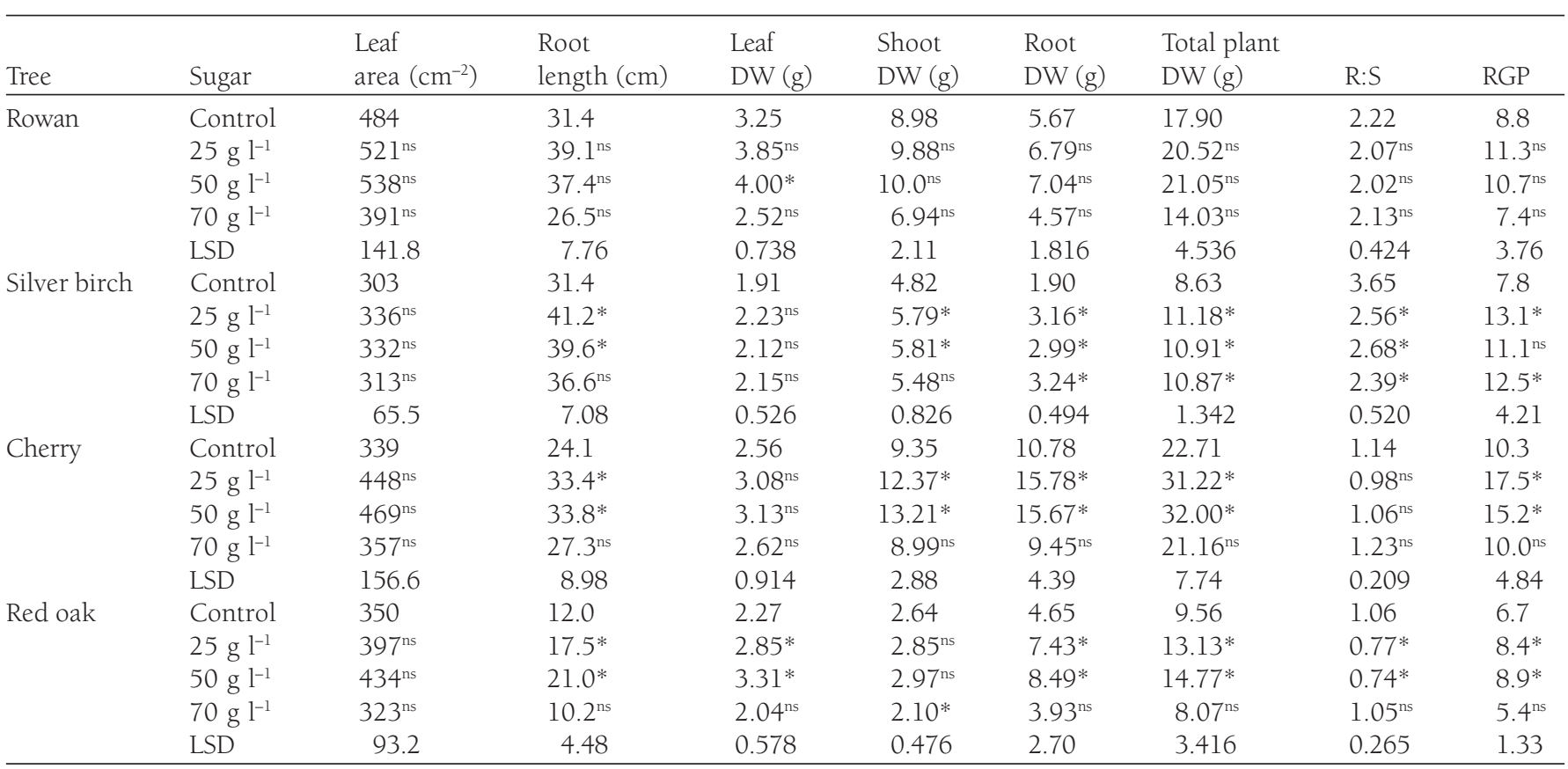

All values mean of 12 trees. $\mathrm{LSD}=$ least significant difference. ${ }^{*}=$ significant at $P<0.05 . \mathrm{ns}=$ not significant.

Table 2. P values for growth and tree vitality of four tree species [Betula pendula (silver birch), Quercus rubra (red oak), Prunus avium (cherry), and Sorbus aucuparia (rowan)] following sugar treatments. $P<0.05$ is considered significant.

\begin{tabular}{|c|c|c|c|c|c|c|c|c|c|c|c|}
\hline \multirow[b]{2}{*}{ Factor } & \multicolumn{6}{|c|}{ Growth } & & & \multicolumn{3}{|c|}{ Vitality } \\
\hline & $\begin{array}{l}\text { Leaf } \\
\text { area }\end{array}$ & $\begin{array}{l}\text { Root } \\
\text { length }\end{array}$ & $\begin{array}{l}\text { Leaf } \\
\text { DW }\end{array}$ & $\begin{array}{l}\text { Shoot } \\
\text { DW }\end{array}$ & $\begin{array}{l}\text { Root } \\
\text { DW }\end{array}$ & $\begin{array}{l}\text { Total plant } \\
\text { DW }\end{array}$ & $\mathrm{R}: \mathrm{S}$ & RGP & $\mathrm{Fv} / \mathrm{Fm}$ & $\mathrm{Pn}$ & $\begin{array}{l}\text { Chlorophyll } \\
\text { content }\end{array}$ \\
\hline Species & $<0.001$ & $<0.001$ & $<0.001$ & $<0.001$ & $<0.001$ & $<0.001$ & $<0.001$ & $<0.018$ & 0.003 & $<0.001$ & $<0.001$ \\
\hline Species $\times$ sugar & 0.688 & 0.625 & 0.151 & 0.312 & 0.016 & 0.103 & 0.271 & 0.402 & 0.505 & 0.445 & 0.098 \\
\hline
\end{tabular}


has shown that, following leaf flush, at least 21 days are required for the photosynthetic apparatus to fully develop and maximum photosynthetic performance to take place, which may account for this recorded effect (Kitao et al. 1998). Results also show a rising chlorophyll content and subsequent increase in photosynthetic activity, mirrored by an increase in chlorophyll fluorescence, in the short term (i.e., weeks 1 through 3). Thereafter, all three tree vitality measurements remain constant until week 12 .

In three of the four test species (cherry, red oak, rowan), lowest fluorescence values, photosynthetic rates, and leaf chlorophyll content were recorded following application of sugar at $70 \mathrm{~g}(2.7 \mathrm{oz})$ per liter of water (Figure 1). No significant improvements in virtually all growth parameters at this concentration also indicate that sugars applied at 70 $\mathrm{g}$ per liter have little benefit in reducing transplant shock (Table 1). Application of sugars at high concentrations can result in osmotic stress that can prove detrimental to tree growth (Salisbury and Ross 1985). Initiation of osmotic stress at a sugar concentration of $70 \mathrm{~g}$ per liter of water may account for the nonsignificant effects recorded in this investigation in three of the four test species.

\section{Effect of Sugars on Root and Leaf Growth}

Root vigor was significantly affected by sugar feeding (Table 2). Applications of sugar as a root drench at 25 and $50 \mathrm{~g}$ $(0.9$ and $1.8 \mathrm{oz})$ per liter of water significantly increased $(P<$ $0.05)$ the RGP, root length, and root dry weight by approximately $30 \%$ to $70 \%$ over controls in birch, cherry, and red oak (Table 1). Likewise, an increase in all three root growth measurements of $25 \%$ to $35 \%$ was recorded in rowan following applications of sugar at these two concentrations. However, this increase was not significant. Applications of sugars at $70 \mathrm{~g}(2.7 \mathrm{oz})$ per liter of water had no significant effect on root vigor with one exception, birch, where root dry weight was significantly higher $(P<0.05)$ than controls. Significant increases in the RGP and root length by week 12 indicate not only short-term enhancement of root vigor but that sugars work by enhancing formation of new roots and increasing the length of existing ones. Similar results have been recorded elsewhere [i.e., increased lateral root branching and new root formation following incubation of wheat root systems in sugar solutions (Bingham and Stevenson 1993; Bingham et al. 1997, 1998)]. Such an effect is desirable in a landscape situation where rapid root promotion is required to restore the root crown ratio posttransplanting and thereby reduce transplant shock. Recent evidence has shown that in plants, sugars such as sucrose, glucose, and fructose function not only as substrates for growth but affect sugar-sensing systems that initiate changes in gene expression and subsequent plant growth (Koch 1996). For example, application of sugars to plants leads to the repression of genes involved with leaf growth and photosynthesis, and enhancement of genes involved with carbon remobilization in favor of root development (Koch 1996; Martin et al. 1997). Alternately, application of sugars derived from seaweed extracts to soils have been shown to induce changes in the naturally occurring soil rhizosphere fungal and bacterial populations, resulting in alterations to plant nutrient uptake patterns. Such changes may also have contributed to improved growth recorded in this investigation (Finnie and van Staden 1985; Walsh 1997). Although not explored in this investigation, alterations in gene expression and rhizosphere populations as a result of sugar application may account for improved root vigor recorded at the whole plant level.

Alterations in gene expression to influence carbon remobilization in favor of root over leaf growth would account for no significant increases in leaf area recorded in this investigation and the majority of nonsignificant effects on leaf dry weight in all test species (Table 1). Differences in carbon remobilization between root and leaf tissue would also enhance the root:shoot ratio-a response recorded in birch and red oak $(P<0.05$, Table 1$)$. Although an increase in the root:shoot ratio was recorded in cherry and rowan, differences were nonsignificant. Higher root:shoot ratios are generally associated with increased stress tolerance and improved plant health following planting (Watson and Himelick 1997).

\section{Effect of Sugars on Shoot Growth}

The effects of sugars on shoot dry weight are variable and inconsistent. Applications of sugars had no significant effect on shoot dry weight of rowan, irrespective of concentration. In the case of birch and cherry, only applications of sugar at 25 and $50 \mathrm{~g}(0.9$ and $1.8 \mathrm{oz})$ per liter of water significantly enhanced $(P<0.05)$ shoot dry weight. Contrary to this finding, only sugar applied at $70 \mathrm{~g}(2.7 \mathrm{oz})$ per liter of water significantly increased shoot dry weight in red oak (Table 1). As well as providing structural and stability functions, roots and shoots are also used to store nutrient reserves. Carbon remobilization in favor of root growth may, in some species, also result in remobilization toward shoot growth. Indeed, sucrose is the major photoassimilate transported from source (leaves) to sink tissues (roots and shoots) in higher plants that are hydrolyzed into glucose and fructose to provide energy via respiration (Salisbury and Ross 1985).

In conclusion, applications of sugars at 25 and $50 \mathrm{~g} \mathrm{(0.9}$ and $1.8 \mathrm{oz}$ ) per liter of water improved root vigor of the majority of trees tested and may be useful in reducing transplant shock in landscape plantings. Although further studies are required to understand the mechanistic basis by which improvements in root vigor occurred, sugar feeding may be an area worthy of further research given the fact that sugars are water soluble, nontoxic, environmentally safe, and inexpensive to purchase. 


\section{LITERATURE CITED}

Bingham, I.J., and E.A. Stevenson. 1993. Control of root growth: Effects of carbohydrates on the extension, branching and rate of respiration of different fractions of wheat roots. Physiol. Plantarum 88:149-158.

Bingham, I.J., J.M. Blackwood, and E.A. Stevenson. 1997. Site, scale and time course adjustments in lateral root initiation in wheat following changes in $\mathrm{C}$ and $\mathrm{N}$ supply. Ann. Botany 80:97-106.

_- 1998. Relationship between tissue sugar content, phloem import and lateral root initiation in wheat. Physiol. Plantarum 103:107-113.

Davies, R.J. 1998. Tree establishment: Soil amelioration, plant handling and shoot pruning. Forestry Commission Research Note., Alice Holt, Surrey, U.K.

Davies, M.J., N.A. Hipps, and G. Kingswell. 2002. The effects of indole-3-butyric acid root dips on the root development and shoot growth of transplanted Fagus sylvatica L. and Quercus robur L. seedlings. J. Hortic. Sci. Biotechnol. 77(2):209-216.

Finnie, J.F, and J. van Staden. 1985. The effect of seaweed concentrate and applied hormones on in vitro cultured tomato roots. J. Plant Physiol. 120:215-222.

Fuchs, H.W.M. 1986. Root regeneration of rose plants as influenced by applied auxins. Acta Hortic. 189:101-107.

Gilbertson, P., and A.D. Bradshaw. 1990. The survival of newly planted trees in inner cities. Arboric. J. 14:287309.

Hall, D.O., and K.K. Rao. 1999. Photosynthesis (6th ed.). Cambridge University Press, Cambridge, UK. pp.174-180.

Herbers, K., P. Meuwly, J.P. Metraux, and U. Sonnewald. 1996. Salicylic acid-independent induction of pathogenesis-related protein transcripts by sugars is dependent on leaf developmental stage. Fed. Euro. Biochem. Soc. Lett. 397:239-244.

Kitao, M., T.T. Lei, and T. Koike. 1998. Application of chlorophyll fluorescence to evaluate Mn tolerance of deciduous broad-leaved tree seedlings native to northern Japan. Tree Physiol. 18:135-140.

Koch, K. 1996. Carbohydrate modulated gene expression in plants. Ann. Rev. Plant. Physiol. 47:509-540.

Lichtenthaler, H.K. 1987. Chlorophylls and carotenoids: Pigments of photosynthetic biomembranes. Methods Enzymol. 148:350-382.

Martin, T., H. Hellmann, R. Schmidt, L. Willmitzer, and W.B. Frommer. 1997. Identification of mutants in metabolically regulated gene expression. Plant J. 11(1):53-62.

Meinander, O., S. Somersalo, T. Holopainen, and R.J. Strasser. 1996. Scots pine after exposure to elevated ozone and carbon dioxide probed by reflectance spectra and chlorophyll a fluorescence transients. J. Plant Physiol. 148:229-236.
Naidu, B.P. 1998. Separation of sugars, polyols, proline analogues, and betaines in stressed plant extracts by high-performance liquid chromatography and quantification by ultra violet detection. Aust. J. Plant Physiol. 25:793-800.

Percival, G.C., and J. Gerritsen. 1998. The influence of plant growth regulators on root and shoot growth of containerised trees following root removal. J. Hortic. Sci. Biotech. 73(3):353-359.

Percival, G.C., and J. Hitchmough. 1995. Tree establishment and performance in a cool growing season arboretum. Arboric. J. 19(4):357-371.

Salisbury, F.B., and C.W. Ross. 1985. Plant Physiology (3rd ed.) Wadsworth Publishing Company, Belmont, CA.

von Caemmerer, S., and G.D. Farquhar. 1981. Some relationships between the biochemistry of photosynthesis and the gas exchange of leaves. Planta 153:376-387.

Walsh, U.F. 1997. The Effects of Ascophyllum nodosum Liquid Seaweed Extract on Microbial Growth, Activity and Pathogenicity. Ph.D. thesis, The University of Strathclyde in association with Scottish Agricultural College (SAC), UK.

Watson, G.W., and E.B. Himelick. 1997. Principles and Practice of Planting Trees and Shrubs. International Society of Arboriculture, Champaign, IL.

Williamson, J.D., D.B. Jennings, W.W. Guo, M. Pharr, and M Ehrenshaft. 2002. Sugar alcohols, salt stress, and fungal resistance-multifunctional plant protection? J. Amer. Soc. Hortic. Sci. 127(4):467-473.

Willits, D.H., and M.M. Peet. 2001. Using chlorophyll fluorescence to model leaf photosynthesis in greenhouse pepper and tomato. Acta Hortic. 507:311-315.

Acknowledgments. The author is grateful for funding from the TREE Fund (Hyland Johns Grant).

\author{
R.A. Bartlett Tree Research Laboratory \\ The University of Reading \\ 2 Earley Gate \\ Whiteknights \\ Reading, RG6 6AU \\ United Kingdom
}




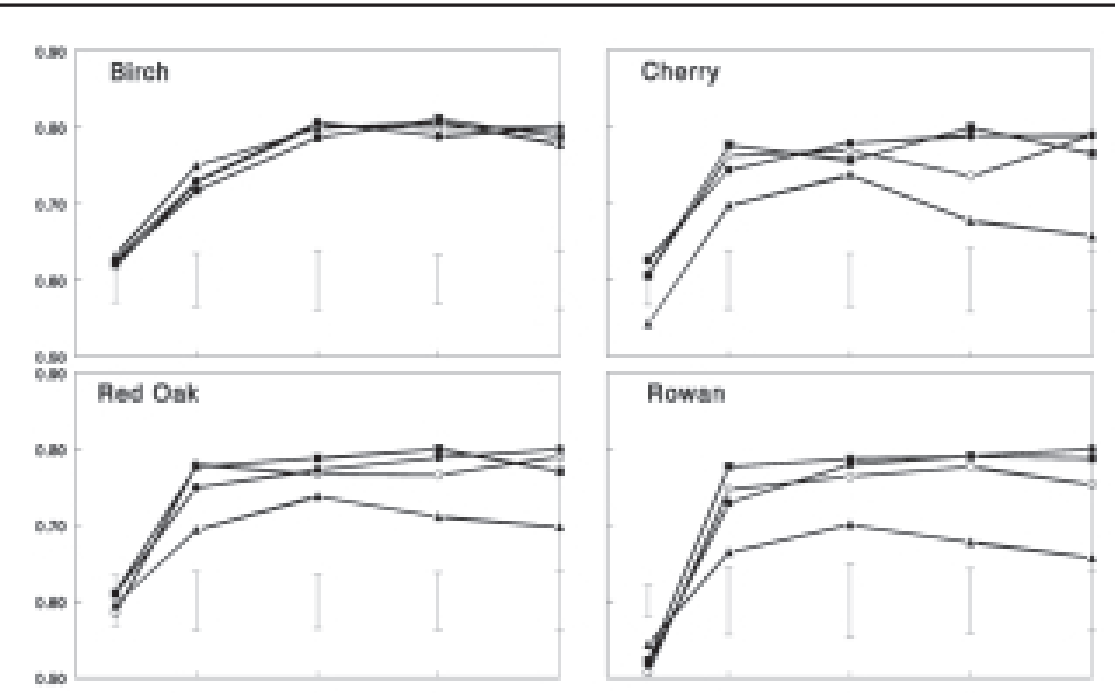

Weeks

Figure 1. Chlorophyll fluorescence ( $\mathrm{Fv} / \mathrm{Fm}$; y axis) of four urban trees with time following sugar feeding at 25,50 , and $70 \mathrm{~g}(0.9,1.8$, and $2.7 \mathrm{oz})$ per liter. All values are mean of 12 trees, 5 leaves per tree. Error bars represent the least significant difference (LSD) at $P<0.05$. $m=$ control, $n=25 \mathrm{~g}$ sugar, $1=50 \mathrm{~g}$ sugar, $\Delta=\mathbf{7 0} \mathrm{g}$ sugar per liter of water.

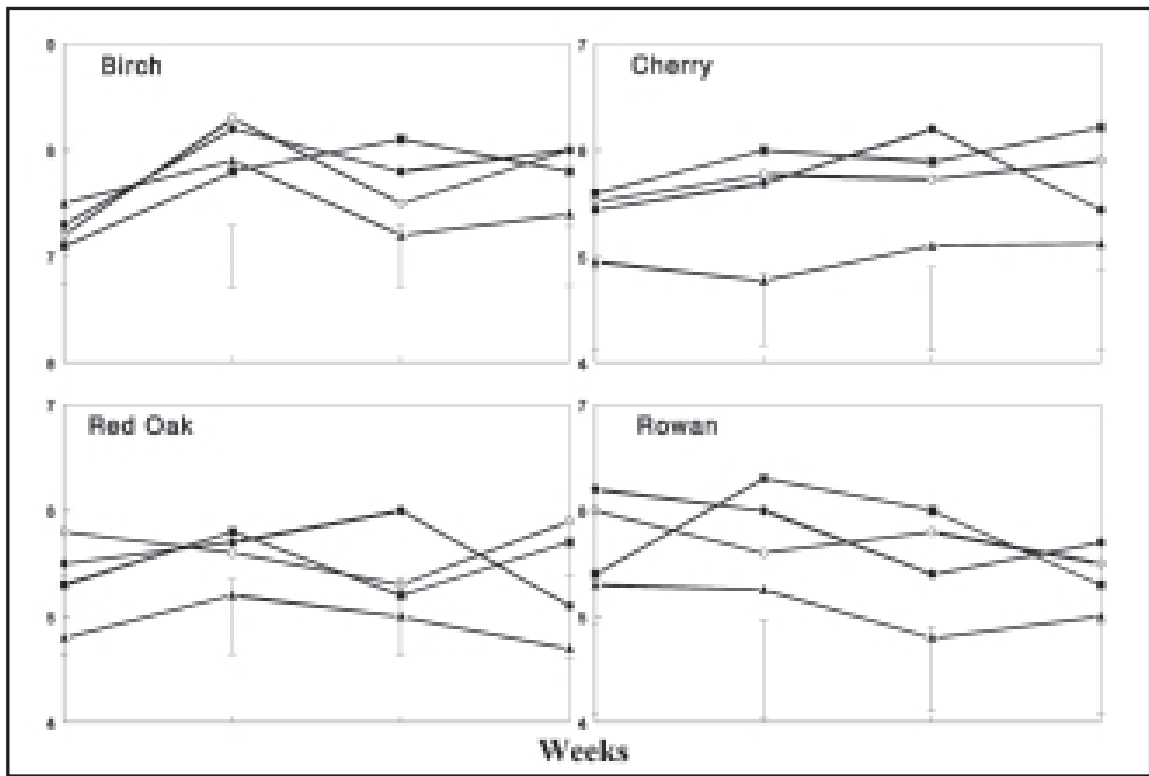

Figure 2. Chlorophyll content (SPAD; y axis) of four urban trees with time following sugar feeding at 25,50 , and $70 \mathrm{~g}(0.9,1.8$, and $2.7 \mathrm{oz})$ per liter. All values are mean of 12 trees, 5 leaves per tree. Error bars represent the least significant difference (LSD) at $P<0.05 \mathrm{~m}=$ control, $\mathrm{n}=\mathbf{2 5} \mathrm{g}$ sugar, $1=\mathbf{5 0} \mathbf{g}$ sugar, $\Delta=\mathbf{7 0} \mathrm{g}$ sugar per liter of water. Note variations in the scale of the $y$ axis. 


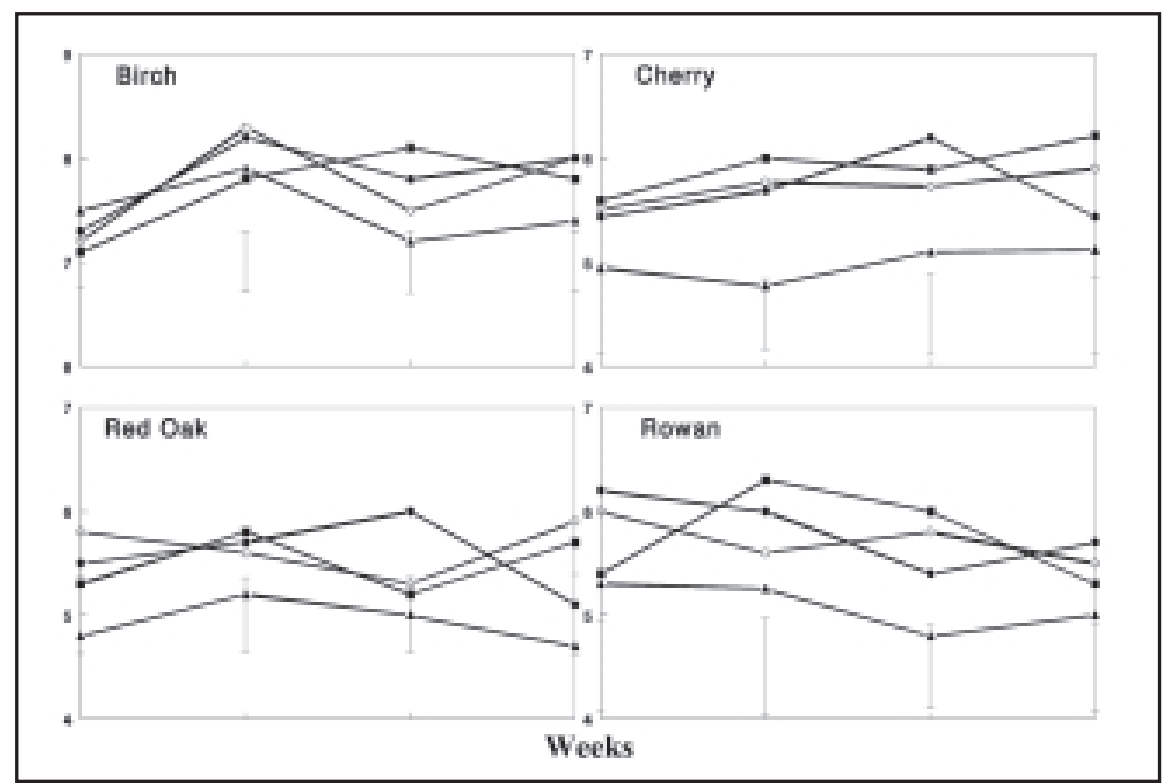

Figure 3. Photosynthetic $\mathrm{CO}_{2}$ fixation (Pn; y axis) of four urban trees with time following sugar feeding at 25,50 , and $70 \mathrm{~g}(0.9,1.8$, and $2.7 \mathrm{oz})$ per liter. All values are mean of 12 trees, 2 leaves per tree. Error bars represent the least significant difference (LSD) at $P<0.05 . \mathrm{m}=$ control, $\mathrm{n}=\mathbf{2 5} \mathrm{g}$ sugar, $1=50 \mathrm{~g}$ sugar, $\Delta=\mathbf{7 0} \mathrm{g}$ sugar per liter of water. Note variations in the scale of the $y$ axis. 
Zusammenfassung. Der Einfluß von Zucker, appliziert als Wurzeldirektgabe mit 25 (0.9), 50 (1.8) und $70 \mathrm{~g}$ (2.7 oz) pro Liter Wasser auf die Wurzel- und Triebenergie, Blattchlorophyllfluoreszenz, Photosyntheserate und Chlorophyllgehalt in (Betula pendula (Quercus rubra, (Prunus avium) und, (Sorbus aucuparia) untersucht. In Silberbirke, Kirsche und Roteiche verstärkte die Applikation von Zucker mit $\leq$ $50 \mathrm{~g}$ (1.8 oz) pro Liter Wasser nach 12 Wochen deutlich die Energie der Wurzeln (Länge, Anzahl neugeformter Wurzeln, Wurzeltrockengewicht). Die Applikationen von $70 \mathrm{~g}$ (2.7 oz) Zucker/Liter Wasser hatten keinen signifikanten Effekt auf die Wurzeln, mit Ausnahme der Silberbirke, wo sich das Wurzeltrockengewicht am Ende des Experiments deutlich gesteigert hatte. Unabhängig von der Art wurden keine signifikanten Effekte auf die Baumvitalität aufgezeichnet. Die Einflüsse auf das Triebwachstum variierten mit einer deutlichen Verbesserung in einigen, aber nicht allen getesteten Arten. Die Ergebnisse zeigen, daß eine Applikation von Zucker auf die Wurzeln möglicherweise eine Hilfe sein kann, neue Gehölze am Standort zu etablieren und Wurzelwachstum nach der Verpflanzung anzuregen.

Resumen. Se investigó la influencia del azúcar (sucrosa) aplicada en las raíces a 25, 50 y $70 \mathrm{~g}$ por litro de agua para mejorar el vigor de raíces y brotes, fluorescencia de clorofila, tasa fotosintética y contenido de clorofila, en abedul (Betula pendula), encino rojo (Quercus rubra), cerezo (Prunus avium) y rowan (Sorbus aucuparia). Aplicaciones de $\leq$ $50 \mathrm{~g}$ (1.8 oz) de azúcar por litro de agua en abedul, cerezo y encino elevaron significativamente el vigor de las raíces (expresado en longitud, cantidad de nuevas raíces y peso seco) por doce semanas. Aplicaciones de azúcar a $70 \mathrm{~g}$ (2.7 oz) por litro de agua no tuvieron efecto significativo en el vigor de las raíces, excepto en abedul donde el peso seco de las raíces al cesar el experimento fue significativamente mejorado. Independientemente de las especies, ningún efecto significativo sobre la vitalidad de los árboles fue medido para fluorescencia de clorofila, tasas fotosintéticas y concentraciones de clorofila. Los efectos sobre el crecimiento de los brotes fueron variables con una elevación significativa en algunas, pero no en todas las especies de prueba. Los resultados indican que la aplicación de azúcares como mejoradores de raíces puede ser capaz de ayudar al establecimiento de nuevos árboles plantados para mejorar el vigor de las raíces después del trasplante.

Résumé. Linfluence de sucres (sucrose) appliqués par trempage des racines à des taux de 25, 50 et 70 g/litre d'eau a été étudiée en regard de la vigueur sur les racines et les pousses, de la fluorescence de la chlorophylle foliaire, des taux de photosynthèse et du contenu en chlorophylle chez le bouleau pleureur (Betula pendula), le chêne rouge (Quercus rubra), le cerisier (Prunus avium) et le sorbier des oiseaux (Sorbus aucuparia). Chez le bouleau pleureur, le cerisier et le chêne rouge, les applications de sucres de d" 50 g/L d'eau ont significativement améliorées la vigueur des racines (longueur des racines, nombre de nouvelles racines, masse racinaire sèche) à la $12^{\mathrm{e}}$ semaine. Les applications de sucres de $70 \mathrm{~g} / \mathrm{L}$ d'eau n'ont eu aucun effet significatif sur la vigueur des racines, à l'exception du bouleau pleureur où la masse racinaire sèche à la fin de l'expérience était significativement améliorée. Peu importe l'espèce, aucun effet significatif n'a été observé sur la vitalité de l'arbre lorsque mesuré au moyen de la fluorescence de la chlorophylle foliaire, des taux de photosynthèse et des concentrations chlorophylliennes. Les effets sur la croissance des pousses étaient variables, avec une amélioration significative observée sur certains tests d'espèces. Les résultats indiquent que l'application de sucres par trempage des racines peut être utile pour favoriser le rétablissement d'espèces d'arbres nouvellement plantés en améliorant la vigueur des racines post-transplantation. 